\title{
A INTERVENÇÃO MUSICAL NO FORTALECIMENTO DO VÍNCULO MÃE-BEBÊ: UM INSTRUMENTO DE APOIO NO PROCESSO DE CUIDADOS DO ENFERMEIRO NEONATOLOGISTA
}

Pôster

Autores deste trabalho:

Larissa Tenorio Andrade Correia: Universidade Federal de Alagoas

Edla Thatiane Caetano da Silva: Universidade Federal de Alagoas

Renise Bastos Farias Dias: Universidade Federal de Alagoas

Nirliane Ribeiro Barbosa: Universidade Federal de Alagoas

Área do Trabalho: Enfermagem pediátrica

Data da submissão:10/08/2018 às 17:40

\section{Justificativa}

O momento em que um recém-nascido (RN) é internado em uma Unidade de Cuidados Intermediários Neonatais (UCIN) é de grande importância para o contato inicial entre mãe e filho e fortalecimento do vínculo entre os dois, por hora rompido no momento do nascimento. Dentre as possibilidades de atuação do enfermeiro neonatal, existe o uso da intervenção musical como ferramenta para tentar reconstruir e restabelecer o vínculo entre mães e seus bebês.

\section{Objetivo(s)}

Identificar os efeitos da música aplicada à mãe durante o período de hospitalização do RN em UCIN, por meio do conteúdo expresso em desenhos.

\section{Método(s)}

Trata-se de uma pesquisa de abordagem qualitativa, aprovada pelo CEP/UFAL sob no 71255417.3.0000.5013. Foram realizadas intervenções musicais com as mães, que realizaram desenhos antes e após a intervenção musical, como um mediador lúdico de expressão dos sentimentos maternos frente à internação de seu filho em UCIN, em busca do fortalecimento do vínculo mãe-bebê. Realizou-se análise de conteúdo de Bardin. $O$ estudo foi realizado com 11 puérperas, em uma Maternidade do agreste alagoano, incluindo as que estavam com filhos hospitalizados na UCIN e que tivessem participado da intervenção musical e excluindo as que não conseguiram completar seus desenhos.

\section{Resultado(s)}

A partir dos desenhos e relatos maternos, foi possível construir as categorias: [1] 0 sentimento materno frente à hospitalização do recém-nascido em UCIN: consequências da separação; [2] A música como fortalecimento de vínculos; e [3] Forma das mães expressarem seus sentimentos através do desenho. Foi possível evidenciar que música e desenho são capazes de proporcionar bem-estar. A música tem a capacidade de acalmar, oferecendo acolhimento e ajudando a fortalecer o vínculo mamãe-bebê. Os desenhos realizados pré-intervenção musical expressaram sentimentos como dor, culpa, medo e tristeza. Pós-intervenção musical 


\section{$4^{\circ}$ Congresso Internacional Sabaró \\ 13 a 15 de \\ setembro de 2018}

Hotel Maksoud Plaza
Alameda Campinas, 150
Säo Paulo- Brosil

predominaram sentimentos de felicidade, superação, fé, esperança e da presença da música no contexto.

\section{Conclusão (ões)}

A prática de enfermagem neonatal deve estar direcionada não somente para o RN em UCIN, mas para a mãe que se encontra em situação de fragilidade. Para isso, é preciso considerar acolhimento, escuta individualizada e de qualidade, tendo sido evidenciado que a intervenção musical e o desenho são possíveis instrumentos para esta abordagem. 